Meta

Journal des traducteurs

Translators' Journal

\title{
Une théorie brésilienne de la traduction littéraire ? Regards entre tradition et rupture
}

\section{Germana Henriques Pereira de Sousa}

Volume 60, numéro 2, août 2015

$60^{\mathrm{e}}$ anniversaire. Les horizons de la traduction : retour vers le futur $60^{\text {th }}$ Anniversary. Translation's Horizons: Back to the Future

60mo aniversario. Los horizontes de la traducción: regreso al futuro

URI : https://id.erudit.org/iderudit/1032891ar

DOI : https://doi.org/10.7202/1032891ar

Aller au sommaire du numéro

Éditeur(s)

Les Presses de l’Université de Montréal

ISSN

0026-0452 (imprimé)

1492-1421 (numérique)

Découvrir la revue

Citer ce document

Henriques Pereira de Sousa, G. (2015). Une théorie brésilienne de la traduction littéraire ? Regards entre tradition et rupture. Meta, 60(2), 340-340.

https://doi.org/10.7202/1032891ar d'utilisation que vous pouvez consulter en ligne. 


\title{
Une théorie brésilienne de la traduction littéraire? Regards entre tradition et rupture
}

\author{
Germana Henriques Pereira de Sousa \\ Universidade de Brasilia, Brasilia, Brésil \\ germanahp@gmail.com
}

L'objet de cette comunication est de réfléchir sur les horizons de la traduction littéraire au Brésil des importantes contributions d'Haroldo de Campos à la théorie de la traduction littéraire, de façon à regarder la tradition critique brésilienne et en même temps porter un regard vers l'avenir: qu'en est-il de la réflexion critique sur la traduction littéraire aujourd'hui au Brésil après plus de 50 ans d'existence de la «théorie de la transcréation », d'Haroldo de Campos. Pour ce faire, nous prétendons vérifier s'il existe une "théorie de la traduction littéraire brésilienne»; présenter et examiner les contributions des plus importants historiciens, critiques et théoriciens qui seraient susceptibles de la fonder, en cherchant à voir où se tournent les regards contemporains entre tradition et ruptures: Paulo Rónai, Haroldo de Campos, José Paulo Paes, Nelson Ascher, Mário Laranjeira, Paulo Henriques Brito, Álvaro Faleiros, entre autres.

Germana Henriques Pereira est professeure à l'Université de Brasilia au Département de Langues Étrangères et Traduction - LET, depuis 1992, où elle est Professora Associada I. Elle fait partie de deux programmes de recherche, en Littérature où elle encadre doctorants et étudiants de Master en histoire, critique et études comparées; et en traductologie [Estudos da tradução], où elle est responsable du programme et encadre des étudiants de master sur histoire, théorie et critique de la traduction littéraire. Ses ouvrages et articles les plus récents sont Tradução na sala de aula (org. avec Gorovitz; Araújo, Ed. da Universidade de Brasília, 2014) et "Tradução e sistema literário: As contribuições de Antonio Candido para os estudos da tradução", Cadernos de Tradução, vol. 35, nº 1, 2015. 